\title{
The Formation of Anti-Victim Personality in the Context of Sports
}

\section{La formación de la personalidad anti-víctima en el contexto de los deportes}

\section{T.P. Budyakova}

Bunin Yelets State University, Yelets, Russia ORCID: https://orcid.org/0000-0003-1739-837X

*Correspondence

Email: budyakova.t@bk.ru
Cite as:

Budyakova, T. P. (2020). The Formation of Anti-Victim Personality in the Context of Sports. Propósitos y Representaciones, 8 (SPE3), e703. Doi: http://dx.doi.org/10.20511/pyr2020.v8nSPE3.703 


\section{Summary}

In sports pedagogy, there is the problem of the formation of an athlete's personality, resistant to various factors of victimization. In the framework of the present study, the author applied the case method and interviews with elite athletes along with the method of victimological analysis. Totally, 20 interviews were processed and 40 cases were analyzed by means of qualitative and quantitative content analyses. It was revealed that both victim and anti-victim personalities of elite athletes have almost the same basic substructures (clusters). However, the content of these clusters is different. The personality structures of the athletes that demonstrate the phenomenon of victim personality include such personal affective complexes as the authority complex, the superiority complex and the guilt complex. The structure of anti-victim personality comprises a system of personality attitudes that do not allow athletes to treat themselves as victims, namely to move forward despite obstacles; to regard defeats as valuable experience, etc. It has been proven that unsportsmanlike behavior is a predictor of victim personality among elite athletes. Manifestations of unsportsmanlike behavior testified the athlete's victim complex that stimulated such incorrect behavior. It was reasoned that high-performance sport is a predictor of the anti-victim personality of the winner only under certain conditions. Anti-victim personality does not allow itself to be perceived as a victim, using psychological attitudes to overcome the difficulties of a sports life, including defeats.

Keywords: Athlete's Personality; High-Performance Sport; Anti-Victim Personality; Victim Personality; Elite Athletes.

\section{Resumen}

En la pedagogía deportiva, existe el problema de la formación de la personalidad del deportista, resistente a diversos factores de victimización. En el marco del presente estudio, el autor aplicó el método del caso y las entrevistas con atletas de élite junto con el método de análisis victimológico. En total, se procesaron 20 entrevistas y se analizaron 40 casos mediante análisis de contenido cualitativo y cuantitativo. Se reveló que tanto las personalidades de las víctimas como de los anti-víctimas de los deportistas de élite tienen casi las mismas subestructuras básicas (clusters). Sin embargo, el contenido de esos grupos es diferente. Las estructuras de personalidad de los atletas que demuestran el fenómeno de la personalidad de víctima incluyen complejos afectivos personales como el complejo de autoridad, el complejo de superioridad y el complejo de culpa. La estructura de la personalidad de la víctima comprende un sistema de actitudes de la personalidad que no permite a los deportistas tratarse a sí mismos como víctimas, es decir, seguir adelante a pesar de los obstáculos; considerar las derrotas como una experiencia valiosa, etc. Se ha demostrado que el comportamiento antideportivo es un predictor de la personalidad de víctima entre los atletas de élite. Las manifestaciones de comportamiento antideportivo atestiguan el complejo de víctima del atleta que estimula ese comportamiento incorrecto. Se razonó que el deporte de alto rendimiento es un predictor de la personalidad antivíctima del ganador sólo bajo ciertas condiciones. La personalidad anti-víctima no se deja percibir como una víctima, usando actitudes psicológicas para superar las dificultades de una vida deportiva, incluyendo las derrotas.

Palabra clave: Personalidad de Atleta; Deporte de Alto Rendimiento; Personalidad AntiVíctima; Personalidad de Víctima; Atletas de Elite.

\section{Introduction}

Currently, in the psychological and pedagogical literature, issues involving young people in physical education and sports have gained much attention from academics. Modern research on the psychology of physical education and sports provides evidence that the motivation for these activities is more sustainable when it is internal, i.e., independent of external factors (Kalajas- 
Tilga et al., 2019). However, the mechanisms of the internal motivation formation and the whole system of intrinsic motivators for physical culture and sports remain understudied.

Engagement in sports, especially high-performance ones, helps individuals form personal role models, and this is especially true among young people. Such role models have become important personal factors sustaining their attention and motivation for sports (Gladilina et al., 2018; Gaffar et al., 2019). However, although such an influence on the individual has been confirmed, this issue has not been sufficiently studied, except the aspect of youth attention to the non-sports interests of elite athletes (Ronkainen et al., 2019).

Some attempts have been made to study scientifically the characteristics of elite athletes compared to other athletes. Differences in family values, integrity, and readiness for training have not been reported. However, a significant difference has been established in relation to success and non-success as well as the application of antiphobic attitudes, among others. In addition, elite athletes establish their priority of the sport over other activities and pay attention not only to the results but also to enhancing their competence (Hardy et al., 2017).

Another important problem in this field is the formation of the elite athletes' personalities. As popular role models, elite athletes are not always satisfied with their personalities and do not behave properly in all life and sports situations. Sometimes they even need psychiatric help. In fact, cases of suicide due to sports failures or removal from sports are frequent (Glick \& Horsfall, 2005; Baum, 2005). Symptoms of professional burnout have also been identified even among young elite athletes (Gerber et al., 2018). Therefore, special programs are developed for working with elite athletes with the aim of forming their personalities through the establishment of social institutions of mentoring (Sotiriadou \& Shilbury, 2009; Sandardos \& Chambers, 2019).

In accordance with the abovementioned information, we can assume that some elite athletes suffer from what is called the "victim personality," which mainly features a "victim complex." The term "victim" came from the Latin word victima. This complex is a combination of such personality affective complexes as the inferiority complex, guilt complex, and so on. All these complexes prevent an athlete from showing the best results and make him/her suffer from failures that may require mental health rehabilitation, especially after experiencing defeats (Budyakova \& Nizhnik, 2020). Another problem is doping use in elite sports. Athletes consider this a shameful behavior, and someone who engages in doping clearly cannot be a role model (Bloodworth \& McNamee, 2010; Platonov, 2003).

Studies have shown that difficulties either temper the athlete or make him/her weak (John et al., 2019). In some cases, defeats can either lead to the development of a victim personality or an anti-victim personality. A person who has an anti-victim personality is able to cope with difficulties, thus preventing him/herself from being perceived as a victim. Such an individual has special resources (i.e. anti-victim personality characteristics) for protecting oneself from the negative impacts of the environment (Budyakova \& Nizhnik, 2020).

Some scientists suggest using images of athletes from ancient Greek mythology as role models in sports, as the personalities of real athletes are rather ambiguous (Frias et al., 2015). However, in sports, career development is usually non-linear (Debois et al., 2015). Therefore, models in sports should be real individuals so as not to disappoint sports fans.

Depending on internal personality factors, engagement in sports, especially elite sports, can lead to the formation of either a victim or anti-victim personality. The authors of the present study attempted to determine which personality factors contribute to the formation of such personalities. In other words, we tried to figure out which of the characteristics of an athlete's personality can be considered as victim or anti-victim qualities. 


\section{Materials and Methods}

Research hypotheses:

1. The personality complexes of elite athletes have specific features due to their high sports profiles.

2. Unsportsmanlike behaviors among elite athletes are a predictor of victim personality.

3. Engagement in high-performance sports is a predictor of a winner's anti-victim personality only under certain conditions.

Research methods: case-method, victimological analysis, and active interviews.

The case method was applied to analyze actual sport situations. In the present research, we collected factual data confirming the development of victim or anti-victim personalities among athletes. As a rule, these are examples of the athletes' unsportsmanlike behaviors or demonstrations of acts of courage in unusual situations.

The authors of the present study also combined the method of active interviews with the victimological analysis. The latter introduces a combination of specially targeted analytical operations, which provide information about the manifestations of the victim personality characteristics of a respondent. This method was applied to study the conditions of the athletes' personality functioning, as reflected in the active interviews. The scheme of victimological analysis is as follows:

a) identification and analysis of the elite athletes' typical response to sports success and failure;

b) identification and analysis of the elite athletes' non-typical response to sports success and failure;

c) identification of the features of the losing athletes' victim complex;

d) identification of the athletes' victim or anti-victim personality traits.

In conducting the research, the authors used the texts of active interviews with elite athletes along with special case studies on major events that occurred in their lives. A total of 20 interviews were processed, and 40 cases were analyzed.

The data from the interviews and case studies were processed by means of qualitative and quantitative content analyses. The occurrences of the studied factors in the study group were expressed in percentage values.

\section{Results}

According to the results of the analysis and generalization of case studies and interviews, we discovered that both victim and anti-victim personalities have practically the same basic substructures (clusters). However, the contents of these clusters were different. The following clusters of both the victim and anti-victim personalities determined the processes of victimization or counteraction to it: motivational, conative, socio-psychological, personal, locus of control, and characterological. Only one difference was revealed: the structure of the victim personality included a pronounced cluster ("personality complexes"), which was either pronounced or not so pronounced in the anti-victim personality (Tables 1 and 2).

Table 1.

Content Analysis of the Cases and Interviews with Athletes (Victim Traits of the Athletes' Personalities) 
Victim Traits of Personality
Frequency of the

Factor Occurrence, $\mathrm{n}$

(\%)

\begin{tabular}{|c|c|}
\hline Motivational Traits of Personality: & \\
\hline - an ambition to always look like a winner & $43(71 \%)$ \\
\hline $\begin{array}{c}\text { - to humiliate the opponent physically and psychologically in } \\
\text { case of a failure, }\end{array}$ & $23(38 \%)$ \\
\hline $\begin{array}{l}\text { - focus only on the result, not the process; the lack of a } \\
\text { motivation shift towards the goal }\end{array}$ & $19(31 \%)$ \\
\hline - external motives (competitions broadcast on television, etc.) & $55(91 \%)$ \\
\hline $\begin{array}{l}\text { - attitude to sport as a means to prove that the personality of a } \\
\text { particular athlete is the best (perfectionistic motive) }\end{array}$ & $49(82 \%)$ \\
\hline \multicolumn{2}{|l|}{ Conative Traits of Personality: } \\
\hline - inability to resist alcohol addiction; & $21(35 \%)$ \\
\hline $\begin{array}{l}\text { - inability to withstand an external pressure from the press } \\
\text { and fans }\end{array}$ & $30(50 \%)$ \\
\hline - suffering violence (including sexual) from a coach; & $12(20 \%)$ \\
\hline - instability in a situation of intentional negative & $13(22 \%)$ \\
\hline \multicolumn{2}{|l|}{ Personal Attitudes } \\
\hline $\begin{array}{l}\text { - treating an opponent with disrespect, tendency for } \\
\text { humiliation; }\end{array}$ & $22(37 \%)$ \\
\hline - treating an opponent as an enemy; & $34(57 \%)$ \\
\hline - treating fans with disrespect; & $25(42 \%)$ \\
\hline - attitude of prohibition violation; & $40(67 \%)$ \\
\hline - attitude of intrusion into another athlete's private space; & $31(52 \%)$ \\
\hline - possibility of unsportsmanlike behavior & $44(73 \%)$ \\
\hline \multicolumn{2}{|l|}{ Locus of Control } \\
\hline - tendency to blame coach for loosing & $31(52 \%)$ \\
\hline - tendency to blame opponent for loosing & $18(30 \%)$ \\
\hline
\end{tabular}


Personality Complexes

- repressed authority complex

$41(68 \%)$

- guilt complex

$37(62 \%)$

- superiority complex

$45(75 \%)$

\begin{tabular}{|c|c|}
\hline Socio-Psychological Traits of Personality: & \\
\hline - disability to create the relations with friends; & $12(20 \%)$ \\
\hline $\begin{array}{l}\text { - family conflicts, lack of psychological and organizational } \\
\text { support from relatives; }\end{array}$ & $23(38 \%)$ \\
\hline - underestimation of psychological support; & $12(20 \%)$ \\
\hline - conflicts with the coach, treating him with disrespect; & $23(38 \%)$ \\
\hline - inefficiency in creation the relations in a team; & $25(42 \%)$ \\
\hline \multicolumn{2}{|l|}{ Character Traits: } \\
\hline - pride & $45(75 \%)$ \\
\hline resentfulness & $38(63 \%)$ \\
\hline - proneness to conflict & $31(52 \%)$ \\
\hline - envy of a stronger opponent & $45(75 \%)$ \\
\hline
\end{tabular}

An analysis of the results introduced in Table 1 shows that the personality structures of the athletes that demonstrate victim behavior includes such personality complexes as a repressed authority complex, a superiority complex, and a guilt complex. The repressed authority complex was described by the Polish psychologist Reykowski (1979). This complex includes a system of affectively charged thoughts about the possible or real loss of personality authority in the minds of others. The manifestations of repressed (lost) authority complex were identified in $41(68 \%)$ interview texts and case studies that described unsportsmanlike behavior. One of the most frequent manifestations of this complex is physical violence against the winner of the competition.

The superiority complex is based on the personality ambition to be recognized as superior over the others and the requirement to be treated as an exceptional person (Hyell \& Ziegler, 1992). The materials of the study contain 45 (75\%) such manifestations. It is significant that the athletes in the studied cases, who claimed the role of the victim, were often perceived as victims, although objectively they simply demonstrated the characteristics of their personality. Obviously, the presence of a superiority complex, which is based on high self-esteem, is caused by the personality that has this complex.

Guilt complex was identified in situations of doping offences. Most athletes that were caught using doping and disqualified from the competition find personal resources to overcome the victim complex by demonstrating anti-victim traits. However, some of them become demoralized, turning into a victim personality. These conclusions are also supported by other researchers (Hong et al., 2020). 
Personality complexes lead to the occurrence of the athletes' character traits that are peculiar for victim personality, namely: pride, resentfulness, proneness to conflict, and envy of a winner.

Personality is a systemic formation based on victim complex that mediates other characteristics of victim mentality.

The locus of control of the victim personality is specified with blaming other people in problems and sports failures, such as: coach, teammate, fans, etc.

It was discovered that the following personality attitudes characterize the athletes' victim personalities: treating an opponent as an enemy, attitude of prohibition violation, possibility of unsportsmanlike behavior, etc. Victim qualities of the personality are also expressed in the athletes' motivation. Thus, as a rule, a victim personality is dominated by a perfectionistic motive, expressed in an ambition to look like a winner and external motives (the desire for sports fame), etc.

The structure of anti-victim personality is different. This is confirmed with the results of the present study introduced in Table 2 .

Table 2.

Content Analysis of the Cases and Interviews with Athletes (Anti-Victim Traits of the Athletes' Personalities)

\begin{tabular}{|c|c|}
\hline Anti-Victim Traits of Personality & $\begin{array}{l}\text { Frequency of the Factor } \\
\text { Occurrence, } \mathrm{n}(\%)\end{array}$ \\
\hline \multicolumn{2}{|l|}{ Motivational Traits of Personality: } \\
\hline - focus only on the result, achievement & $41(68 \%)$ \\
\hline $\begin{array}{l}\text { - cyclical motivation: to set a goal, to achieve it and then } \\
\text { again, according to the same scheme }\end{array}$ & $43(71 \%)$ \\
\hline - regard sport and physical education as an labor & $51(85 \%)$ \\
\hline $\begin{array}{l}\text { - awareness of the importance of sports and physical } \\
\text { education for the personality development }\end{array}$ & $59(98 \%)$ \\
\hline - motivation to keep fit & $51(85 \%)$ \\
\hline - the presence of ideal athlete personality to follow & $34(57 \%)$ \\
\hline $\begin{array}{l}\text { - focus not only on the result, but on the competition process } \\
\text { and training; }\end{array}$ & $32(53 \%)$ \\
\hline - not to quit sports due to for unfulfilled ambitions & $4982 \%)$ \\
\hline - external motives (competitions broadcast on television, etc.) & $12(20 \%)$ \\
\hline $\begin{array}{c}\text { - dual motivation, i.e., to prove to oneself, not just to the } \\
\text { opponent }\end{array}$ & $55(91 \%)$ \\
\hline
\end{tabular}




\section{Conative Traits of Personality:}

- be able to wait until it starts to work out

$58(96 \%)$

- regularity of training

$55(91 \%)$

- stability in a situation of intentional negative psychological

$25(42 \%)$

pressure from administrative sports and related authorities.

Personal Attitudes:

- positive attitudes: move forward despite obstacles

$45(75 \%)$

- to regard defeats as valuable experience

$57(95 \%)$

- understanding that difficulties are part of the profession

$48(80 \%)$

- among others, to set a goal to assay one's strength and

$5998 \%)$

compare oneself to other athletes

- attitude to adopt the means of emotional regulation of

personality

- impossibility of unsportsmanlike behavior

$33(55 \%)$

- the competitor respect

$3863 \%)$

\section{Locus of Control}

tendency to blame oneself for loosing and not the others

$45(75 \%)$

\begin{tabular}{|c|c|}
\hline Socio-Psychological Traits of Personality & \\
\hline - ability to create the relations with friends & $34(57 \%)$ \\
\hline $\begin{array}{l}\text { - good family relations, psychological and organizational } \\
\text { support from relatives }\end{array}$ & $44(73 \%)$ \\
\hline - understanding of psychological support significance & $55(91 \%)$ \\
\hline - positive attitude to the coach personality & $43(71 \%)$ \\
\hline \multicolumn{2}{|l|}{ Character Traits } \\
\hline - Open-mindedness; & $19(31 \%)$ \\
\hline - agreeableness & $35(58 \%)$ \\
\hline - sociability & $41(68 \%)$ \\
\hline - empathy & $43(71 \%)$ \\
\hline
\end{tabular}

Among the elite athletes, showing the phenomenon of anti-victim personality, almost no personality complexes were identified. Obviously, this does not mean that they are completely 
absent. However, it can be confidently stated that anti-victim personality is able to overcome these complexes.

The research works of the problem provide the description of the techniques used by the successful athletes to avoid the occurrence of affective complexes and their impact on the behavior. One way to prevent complexes is to refuse to read the sports press (Hayes et al., 2020). Another way, used to reduce the negative impact of the defeat factor on the athlete's personality, was to develop a psychological attitude in relation to sports events, i.e., a medium between the treating sport as a game and as a war. "It is not exactly a war and not exactly a game" (Stovitz \& Satin, 2004).

The authors of the present study identified another methods and attitudes that form the athlete's personal resistance to victim factors. First of all, it is a system of personal attitudes that do not allow an athlete to treat himself as a victim. These are positive attitudes such as: to move forward despite obstacles; to treat defeat as valuable experience; to understand that difficulties are part of the profession; to set a goal to assay one's strength and compare oneself to other athletes; attitude to adopt the means of emotional regulation of personality; impossibility of unsportsmanlike behavior, and opponent respect. Such attitudes contribute to the formation of the corresponding character traits such as open-mindedness, agreeableness, sociability, empathy, as well as the formation of locus of control, which consists of the ability to take responsibility for the defeat, rather than transfer it to the coach and other people.

The results of the present research showed that both victim and anti-victim personality traits can be manifested in one and the same sports situation.

\section{Discussion}

In previous studies, the author has already emphasized the importance of certain attitudes to the formation of a successful personality in sports (Baturkina \& Budyakova, 2019). The present study shows that successfulness does not always form an anti-victim personality. Some successful athletes demonstrate the phenomenon of victim personality that stimulates unsportsmanlike behavior. An anti-victim personality is formed only in cases of the refusal of unsportsmanlike behavior. It is able to overcome the victim complex in case of defeats and other sports and related problems.

It can be assumed that the formation of victim personality in high-performance sport is influenced by objective and subjective factors. Objective factors, which are described in scientific research, include the very functioning system of high-performance sport. It is noted that the athlete is the most vulnerable in this complex system with a number of different factors (managers, coaches, sponsors, etc.) (Kovalenko, 2015). Pressure on the athlete from the administration of the team and sports officials subconsciously causes the phobia of defeat and forms the victim complex.

A separate issue and an objective factor influencing the personality of a modern athlete, is the development of the political function of high-performance sports. Sport is aligned with the political goals when it becomes a significant political tool. Thus, the athlete is required to win at all costs, which increases the pressure on his mentality and stimulates the use of unsportsmanlike means of winning (unsportsmanlike behavior, the use of doping, etc.). Currently, high-performance sports have become an instrument of political struggle (Glazatov, 2017; Pustovaya et al., 2018).

Some researchers appeal to abandon the commercialization of sports and to popularize the athletes who do not violate sports ethics (Matveev, 2005). The authors of the present study described some subjective factors contributing to the formation of a victim personality, i.e., certain attitudes and other properties of a victim 
personality. Both external and internal factors can be overcome by means of anti-victimization programs that aim to overcome victim complex. For instance, such programs were developed for crime victims (Budyakova, 2014), although they can also be adapted for the formation of an anti-victim personality in sports.

\section{Conclusions}

Summarizing the results of the study, we can declare that all three hypotheses were confirmed.

1. The first hypothesis that the content of personality complexes among elite athletes has its own peculiarities, due to high sportsmanship profile, has been partially confirmed. The superiority complex, as a specific affective complex, reflecting high sportsmanship profile, was identified only among those athletes who demonstrated the phenomenon of victim personality. Most of the elite athletes find a way to overcome this complex. They do not show undue anxiety and concern about the failure, because the structure of their personality includes productive attitudes contributing to effective overcoming of the psychological problems.

It is worth highlighting that the personality of elite athlete is sensitive to the emergence of a superiority complex. Such a complex requires special correction, otherwise psychiatric symptoms or a tendency to alcoholism can be developed.

2. The second hypothesis that unsportsmanlike behavior is a predictor of the victim personality of elite athletes has been fully confirmed. Obviously, all demonstrations of unsportsmanlike behavior testified the existence of the athlete's victim complex that stimulated such improper behavior. The athlete was afraid of his failure or his personality as a loser to be discussed in the press, which stimulated the demonstration of unsportsmanlike behavior.

3. The third hypothesis that high-performance sport is a predictor of the development of the winner's anti-victim personality only under certain conditions has also been fully confirmed. An anti-victim personality is formed only on provision of conscious intentional disposal of the victim complex. An anti-victim personality prohibits being perceived as a victim, using psychological attitudes to overcome the difficulties of a sports life, including defeats.

\section{Acknowledgments}

The reported study was funded by RFBR, project number 20-013-00020 A «Physical culture and sport as predictors of the formation of an antivictivistic personality in people with disabilities and with a health standard».

\section{References}

Baturkina, G. V., \& Budyakova, T. P. (2019). Social perception as a factor in the professional success of a tennis player. Amazonia Investiga, 8(23), 431-439.

Baum, A. L. (2005). Suicide in athletes: A review and commentary. Clinics in Sports Medicine, 24(4), 853-869.

Bloodworth, A., \& McNamee, M. (2010). Clean Olympians? Doping and anti-doping: The views of talented young British athletes. International Journal of Drug Policy, 21(4), 276-282.

Budyakova, T. P. (2014). Characteristics of visual contacts in the process of taking hostages. Voprosy Psikhologii, 3, 96-104.

Budyakova, T. P., \& Nizhnik, G. N. (2020). The phenomenon of victim personality in students with disabilities. Perspectives of Science and Education, 40(3), 396-411.

Debois, N., Ledon, A., \& Wylleman, P. (2015). A lifespan perspective on the dual career of Elite male athletes. Psychology of Sport and Exercise, 21, 15-26. 
Frias, F., Isidori, E., \& Papaellina, C. (2015). Greek mythology and education: From theory to practice. Procedia - Social and Behavioral Sciences, 197, 595-599.

Gaffar, V., Yuniawati, Y., \& Ridwanudin, O. (2019). A study of outdoor recreation motivation and activity preferences. Journal of Southwest Jiaotong University, 54(3). doi:10.35741/issn.0258-2724.54.3.23

Gerber, M., Best, S., Meerstetter, F., Walter, M., Ludyga, S., Brand, S., Bianchi, R., Madigan, D. J., Isoard-Gautheur, S., \& Gustafsson, H. (2018). Effects of stress and mental toughness on burnout and depressive symptoms: A prospective study with young elite athletes. Journal of Science and Medicine in Sport, 21(12), 1200-1205.

Gladilina, I., Yumashev, A. V., Avdeeva, T. I., Fatkullina, A. A., \& Gafiyatullina, E. A. (2018). Psychological and pedagogical aspects of increasing the educational process efficiency in a university for specialists in the field of physical education and sport. Espacios, $39(21), 11$.

Glazatov, A. V. (2017). Sport of the highest achievements as an instrument of the policy of forming a positive image of the state: domestic political dimension. "P.O.I.S.K." (Policy. Social Science. Art. Sociology. Culture, 5(64), 16-22.

Glick, I. D., \& Horsfall, J. L. (2005). Diagnosis and psychiatric treatment of athletes. Clinics in Sports Medicine, 24(4), 771-781.

Hardy, L., Barlow, M., Evans, L., Rees, T., Woodman, T., \& Warr, C. (2017). Chapter 1: Great British medalists: Psychosocial biographies of Super-Elite and Elite athletes from Olympic sports. Progress in Brain Research, 232, 1-119.

Hayes, M., Filo, K., Geurin, A., \& Riot, C. (2020). An exploration of the distractions inherent to social media use among athletes. Sport Management Review. doi:10.1016/j.smr.2019.12.006

Hong, H. J., Hennin, A., \& Dimeo, P. (2020). Life after doping - A cross-country analysis of organisational support for sanctioned athletes. Performance Enhancement \& Health, $8(1), 100161$.

Hyell, L., \& Ziegler, D. (1992). Personality theories: Basic assumptions, research, and applications. New York: McGraw-Hill Publishing.

John, J. M., Groppe, H., \& Thiel, A. (2019). The role of critical life events in the talent development pathways of athletes and musicians: A systematic review. Psychology of Sport and Exercise, 45, 101565.

Kalajas-Tilga, H., Koka, A., Hein, V., Tilga, H., \& Raudsepp, L. (2019). Motivational processes in physical education and objectively measured physical activity among adolescents. Journal of Sport and Health Science. doi:10.1016/j.jshs.2019.06.001

Kovalenko, N. (2015). Problems faced by athletes in sports of the highest achievements. Science in Olympic Sports, 1, 71-83.

Matveev, S. (2005). Ethics in sports or "fair play": utopia or reality. Science in Olympic Sports, 2, 6-18.

Platonov, V. N. (2003). Doping and the fight against it in modern sports: a look at the problem. Sports Medicine, 1, 41-67.

Pustovaya, I. V., Pustovaya, M. V., \& Kovaleva, M. V. (2018). Sport of the highest achievements as an instrument of political struggle in international relations. Discourse, 12(26), 43-52.

Reykowski, J. (1979). Experimental psychology of emotions. Moscow: Progress.

Ronkainen, N. J., Ryba, T. V., \& Selänne, H. (2019). "She is where I'd want to be in my career": Youth athletes' role models and their implications for career and identity construction. Psychology of Sport and Exercise, 45, 101562.

Sandardos, S. S., \& Chambers, T. P. (2019). "It's not about sport, it's about you": An interpretative phenomenological analysis of mentoring elite athletes. Psychology of Sport and Exercise, 43, 144-154.

Sotiriadou, K., \& Shilbury, D. (2009). Australian Elite athlete development: An organisational perspective. Sport Management Review, 12(3), 137-148.

Stovitz, S. D., \& Satin, D. J. (2004). Ethics and the athlete: why sports are more than a game but 
less than a war. Clinics in Sports Medicine, 23(2), 215-225.

Propósitos y Representaciones Sep. 2020, Vol. 8, SPE(3), e703 http://dx.doi.org/10.20511/pyr2020.v8nSPE3.703 